Mid-American Review of Sociology

Scheznider, Alvin

1972 The Emergence of Brother Me Symbols of Solidarity Among Blacks in the Armed Forces; Paper presented at the 67th Annual Meeting of the American Sociological Association.

Vidich, Arthur and Bensman, Joseph

1968 Small Town in Mass Society: Class, Power, and Religion in a Rural Community; Princeton University Press, New Jersey.

Young, Frank

1968 Differentiation and Soldiarity in Agricultural Communities; Human Organization, Vol. 27, No. 4, Winter.

\section{A DEFINITION OF THE CONCEPT OF LAW}

\author{
Alan V. Johnson \\ University of Kansas
}

Mid-American Review of Sociology, 1977, Vol. 2, No. 1:47-71

\begin{abstract}
A definition of the concept of law is developed by drawing on the works of jurists and anthropologists as well as sociologists. Law is conceptualized in terms of Sumner's definition of an institution, the "concept" being the normative law and the "apparatus" being the group engaging in legal action. The rudimentary forms of legal norms and of legal actions which exist in all legal institutions are identified and described. The process by which these rudimentary forms of legal norms and of legal actions develop so as to constitute the wide variety of legal institutions which exist or have existed is also examined.
\end{abstract}

In a recent article Malcolm Feeley (1976:503) observed that: "Most contemporary research on law and society suffers from its unwillingness to even consider a definition of the concept of law and hence the boundaries of investigation." This reluctance is perhaps the most widely shared feature of social scientists interested in law.

This reluctance to consider a definition of the concept of law is not due to a lack of previous attempts to define law. For, as Paul Bohannon (1967:43) points out: "It is likely that more scholarship has gone into defining and explaining the concept of 'law' than any other concept still in central use in the social sciences." Rather, the contemporary reluctance to consider a definition of the concept of law is due to the great variety of contradictory definitions which have been previously developed. These contradictory definitions have led many scholars to refuse to define law altogether and to even regard such a task as almost impossible (Pospisil, 1972). Max Radin (1938:1145) exemplifies these pessimistic scholars when he writes: "Those of us who have 
learned humility have given over the attempts to define law."

The problematic nature of developing a conceptual identification of law is due not to the complexity of the phenomena, but rather to two kinds of erroneous thinking. The first type of erroneous thinking is the assumption that law is not a concept but a phenomenon that somehow can be objectively and absolutely defined. As Leopold Pospisil (1972:6) points out:

Law stands for a concept, for a category composed of individual social phenomena. Although phenomena do exist in the world outside of the mind, categories do not. They are mental constructs, relative in time and space to the individual user and to the purpose for which they have been constructed. Justification of the concept of law, then, does not reside in its objective existence but in its heuristic value as an analytical device. Thus, since the law concept is not absolute, and since the phenomena dealing with social control is an objective, unsegmented continuum, law can and has been defined in many ways.

Moreover, although a definition should be precise, with an attempt to define exactly the term's semantic boundaries, the factual continuum makes it impossible to place all the phenomena within or without such a category.

The second type of erroneous thinking which has led to the overly problematic nature of developing a conceptual identification of law is the insistence that essentially empirical questions about law be answered by conceptions of law. In other words, some writers fail to distinguish two separate questions regarding the study of law: 1) what is law? and 2) what is to be asked about law? Concepts of law are directed toward answering the first question, but not the second. Questions about law-such as what is the function of law, or how does law develop-are predominantly empirical and cannot be answered by conceptual analysis (Gibbs, 1973).

In this paper I shall attempt to develop a conceptual identification of law, the value of which lies in its utility as an analytical device which can be used in investigating a wide variety of empirical questions concerned with law. Many of the elements constituting this conception of law have been borrowed from jurists and anthropologists as well as sociologists. Although jurists and anthropologists are concerned with questions, problems, and subsets of phenomena which are different from the questions, problems, and subsets with which sociologists are concerned, the complex of phenomena constituting law is the same no matter who studies it. In this sense, the concept of law which is to be developed in this paper is interdisciplinary.

This concept of law is based on the assumption that part of what we refer to as "law" is one aspect or part of the phenomenon of culture, and part is one aspect or part of the phenomenon of social organization (Warriner, 1976). Conceptualizing law in these terms will involve two steps: 1 ) isolating law from other related, but different phenomena; and 2) describing law in terms of universal phenomena. Given the diversity of actors, functions and phenomena which have been subsumed under the concept "law," it is important to develop a universal classification of elements that should be included in what we mean by law. The classification should be applicable across cultures.

\section{THE CONCEPT OF LAW}

Before proceeding to these discussions, it might be useful at this point to briefly outline the class of phenomena included within the concept of law. The term "law" refers to two main types of phenomena: 1) a body of statements (written or oral) constituting the rules, norms, and prescriptions (i.e., "laws") which have either been explicitly formulated, or which have come to be accepted as authoritative and legitimate; and 2) actions which express or implement these statements of the rules, and which are of two kinds: a) those which formulate, codify, refine, elaborate on, supplement, and explain the rule statements; and b) those which use the rules as a basis for sanctioning rule violators, or as a basis for adjudicating conflicts between actors.

Law in these terms is best conceptualized as an institution. The institution of law is thus composed of normative law, a body of statements, and legal action, a set of organized activities which express or implement the body of statements. As the following 
discussion will indicate, law as an institution emerges when normative law becomes differentiated from the other elements of culture, and when legal action becomes differentiated from the other elements of social organization, that is, when legal action is assigned to special actors who formulate and implement the normative law.

The value of concepts lies not in their correspondence to phenomenal reality, but rather in their capacity to structure phenomenal reality. Concepts are tools which provide us a means for making some sense out of the infinite complexity of phenomenal reality. Accordingly, concepts are not more or less correct or incorrect, but rather more or less useful or not useful. The concept of law which will be developed in this paper is a useful tool for several reasons.

This concept of law is useful because it includes both the cultural and the social organizational aspects of law. Law is more than simply a matter of abstract rules, principles, or legal decisions because these norms must be created, interpreted, enforced, and adjudicated (Selznick, 1961). Similarly, law is more than simply a matter of enforcement and the settlement of disputes because these actions are intended to be guided by norms (Selznick, 1968). In studying law we must consider both the norms and the actions, i.e., both parts of the institution of law. An undue emphasis on one at the expense of the other will only result in an incomplete picture.

Another reason this concept of law is useful is because it conceptualizes normative law in terms of cultural phenomena and legal action in terms of social organizational phenomena. In other words, it does not define normative law in terms of legal action or vice versa. Such a conception allows us to empirically determine the extent to which the actions which in fact occur correspond to the prescriptions of how the actions should occur. The extent to which action corresponds to normative law must be empirically determined, not conceptually assumed.

A closely related reason this concept of law is useful is because it accounts for the fact that the external objects (norms) which represent legal collective understandings may take one of two forms. Legal norms may take the form of explicit abstract rules which are either written or remembered, which make up the content of legal codifications. Legal norms may also take the form of concrete adjudicative decisions. These decisions are normative in the sense that they are regarded as being applicable to all future cases involving similar actions (Pospisil, 1972).

This concept of law does not define law in terms of its function. It does not state, for example, that the function of law is the legitimation of authority, or the protection of the interests of the ruling class, or the reaffirmation of the collective conscience, or the resolution of conflict, or the regulation of behavior. The function or functions of law must be empirically determined, not conceptually assumed.

This concept of law defines law in terms of phenomena existing in all societies and in all functioning subgroups. This is not to say that legal phenomena do not vary a great deal from society to society and from subgroup to subgroup. It is only to say that there exists an identifiable element or attribute which characterizes all legal phenomena and which serves to distinguish legal phenomena from other related but different phenomena, namely, that all legal phenomena are a part of an institution.

This concept of law recognizes the overlapping nature of social phenomena. It identifies the orders of phenomena which are most interrelated with that set which we label "law." Law, power, ethics, custom and morality do not exist in reality as separate and distinct sets of phenomena. Rather, they all belong to the same continuum with imperceptible transitions leading from one to the other (Weber, 1954).

Finally, this concept of law is useful because it recognizes the complexity and variety of legal phenomena. It identifies several different types and subtypes of normative law and of legal action, and it allows for more types to be added. It is elaborate and detailed. Although they can never account for the totality of phenomenal reality, concepts must be elaborated as rigorously and as unequivocably as possible so as to avoid confusion of problems and confusion of phenomena. Furthermore, concepts which are elaborate are more useful in analyzing the singularity of a particular event, as well as the similarity among different events (Freund, 1968). 
ISOLATING LAW FROM OTHER RELATED BUT DIFFERENT PHENOMENA

The first step in developing a conception of law as an institution is to isolate law from other related, but different orders of phenomena. Power, ethics, morality and custom are all intertwined in the set of phenomena we call law. Accordingly, in distinguishing law from these other orders of phenomena, we face two questions: 1) to what extent does law depend upon and is coterminous with power, ethics, morality and custom; and 2) when are these general orders of phenomena a part of law and when are they not? Answering these questions is crucial because of the overlapping nature of social phenomena. Law, power, ethics, and morality do not exist in reality as separate and distinct phenomena, but rather belong to the same continuum with imperceptible transitions leading from one to the other.

Power and law are coterminous to the extent that they share several common elements. Both involve to some extent the direction and control of human action, both imply subordination to authority, and both do not extend beyond a particular social group. Moreover, the existence of legal rights and legal rules necessarily implies power because individuals or groups use power to enforce such rights and rules through the legal institutions. Finally, power and law are intertwined in that the makers, interpreters, administrators, and enforcers of law possess considerable potential and actual power in a society.

Ethics and law are interrelated in two general ways. First, ethical values are often embodied in normative law. For example, prohibitions against murder and theft are ethical values as well as legal rules. Second, one type of ethical value is the ideal of legality. The ideal of legality is a complex body of values about what the legal order should be, what rules and judicial decisions ought to be, how they ought to be created, interpreted, and applied, and what the function of the legal order ought to be. These values often play a controlling part in the development, interpretation, and application of legal rules included within the ideal of legality in our own society are such values as "due process of law," "civil liberties," "equal protection of the law," and "fundamental fairness."
Custom, morality, and law are all intertwined in that they are all directed toward the same environment, namely, the social environment. All three are directed toward relating members of the group to each other and to nonmembers. Furthermore, custom, morality, and law all involve norms of behavior, and to some extent observable regularities of social action (patterns of action which have a typically identical meaning and which are repeated by the actors or simultaneously occur among many actors). A third interrelationship between custom, morality, and law is that certain norms and actions may simultaneously be a part of all three.

Although law to some extent depends upon and is coterminous with power, ethics, morality and custom, these other general orders of phenomena are not always a part of law. The key to determining when these phenomena are a part of law and when they are not lies in the concept of an institution. William Graham Sumner (1967:352) defined an institution in the following manner.

An institution consists of a concept (idea, notion, doctrine, interest) and a structure. The structure is a framework, or apparatus, or perhaps only a number of functionaries set to cooperate in prescribed ways at a certain conjuncture. The structure holds the concept and furnishes instrumentalities for bringing it into the world of facts and action in a way to serve the interests of men in society.

The legal institution, using Sumner's point of view, consists of an apparatus or a specific body of actors who are assigned responsibility for the concept (i.e., "the law"), and who implement that concept by formulating laws and by using them in adjudicating conflicts between parties or between an individual and society. In the terms used in this paper, the "concept" of the legal institution is the normative law (the body of rule statements), and the "apparatus" is the group which engages in legal action (the set of organized activities implementing the normative law). 
Law thus exists on a different level from power, ethics, custom, and morality because it is an institution. Law is separated out from the ongoing activity of the group, and is given a more or less permanent, prevalent, and independent place in the life of the group. Power is a part of the legal institution when it is exercised by the legal apparatus in legal action. Similarly, ethics, custom, and morality are a part of the legal institution when their norms and values are implemented or enforced by the legal apparatus in legal action.

\section{DEFINING LAW IN TERMS OF UNIVERSAL PHENOMENA}

Having isolated the complex of phenomena we call law from the related, but different orders of phenomena we call power, ethics, custom, and morality, the next step in developing a conceptual identification of law is to describe the legal institution. In other words, after we have circumscribed an area of phenomenal reality and labelled it "law," we must describe the complex of phenomena contained in that area. This step is problematic if the concept of law is to be used in cross-societal comparative analysis because the complex of phenomena to which the concept refers must exist in all societies.

Yet it cannot be denied that the legal institution varies a great deal from society to society. The complex of phenomena which makes up the legal institution of U.S. society is considerably different from that which makes up the legal institution of Eskimo society. The U.S. legal institution is made up of federal, state, and local legislatures; appellate and trial courts; jails, prisons, and penitentiaries; federal, state, and local police; lawyers and judges; and a variety of other activities; structures, and actors. The Eskimo legal institution, on the other hand, is primarily made up of the shaman, headmen, and song duels.

Our problem, then, is twofold. First, we must identify and describe the rudimentary forms of legal norms and actions which exist in all legal institutions. Second, we must indicate how these rudimentary forms of actions and norms develop so as to constitute the wide variety of legal institutions which exist or have existed.

\section{THE RUDIMENTS OF THE INSTITUTION OF LAW}

As we saw in the last section, law is an institution composed of a certain set of collective understandings (normative law), and a certain set of social actions (legal action). Accordingly, the first step in describing the rudiments of the legal institution is to explain in what sense it is composed of "understandings" which are "collective" and of actions which are "social."

The "understandings" of the legal institution are prescriptions about how actors should act, rather than descriptions of how actors do in fact act. Members of a group come to agree that certain actions in certain situations are the correct or proper way to act. But that does not mean that most or even some members of the group will act in accordance with these agreements at all times. Indeed, legal understandings often differ from the actual behavior of the members of the group. Prescribed behavior is a set of phenomena different from actual behavior, and normative law is composed of the former, not the latter.

Legal understandings are not simply a commonality or an average of individual prescriptions of proper behavior. Rather, they are a product of interaction, and are in this sense collective understandings. That legal understandings are collective does not imply that all members of the group have participated in the interactions which produced the legal understandings, nor that all members personally accept the understandings, nor that all members have knowledge of the understandings. The fact that legal understandings are collective only implies: 1) that they emerge from interactions between certain individuals who are socially recognized as able to agree upon prescriptions of proper behavior for the group as a whole; and 2) that they are intended and recognized as the official prescriptions of the group.

Legal actions are "social" because their meaning and purpose are shared and recognized not only by the individuals engaged in the action, but also by all members of the group in which the action occurs. Legal actions are recognized by all members of the group because their conception arises in the history of the group and is a result of the characteristics of the group (Warriner, 1970). 
The second step in describing the rudiments of the legal institution is to identify the norms and acts which are fundamental to all institutions of law. Considering the fundamental norms first, there are two types of norms which exist in all legal institutions: 1) primary legal norms prescribing the proper actions in certain circumstances; and 2) secondary legal norms prescribing the proper actions by which the institutional structure implements the primary legal norms. We may call the former set of legal norms substantive law, and the latter set institutional or procedural law.

Institutional law may be further divided into two subtypes of norms which exist in all legal institutions: 1) norms prescribing the proper way to create, interpret, display, state, and recognize substantive norms; and 2) norms prescribing the proper way to detect, adjudicate, and react to violations of the substantive norms (Hart, 1961). We may call the former set of institutional norms elaboration norms, and the latter set enforcement norms.

Turning to the fundamental acts of the legal institution, we also find two types of acts which exist in all institutions of law: elaborating acts and enforcing acts. Elaborating acts are those acts which are actually involved in creating, interpreting, displaying, stating, and recognizing substantive norms, and which are carried out by those with the prescribed power of so acting. Enforcing acts are those acts which are actually involved in detecting, adjudicating, and reacting to violations of the substantive norms, and which are carried out by those with the prescribed power of so acting.

These rudiments of the legal institution are illustrated in the following diagram.

It is important to note that in describing the rudiments of the legal institution, normative law and legal actions have been dealt with separately. Although both normative law and legal action are constituent parts of the legal institution, they are distinct sets of phenomena. We must conceptually separate normative law and legal action because it is possible for each to exist external to the other (Warriner, 1970). It is possible for legal collective understandings to exist as autonomous social facts which are not represented by a particular set of legal actions. Examples of 
of the state. Law neither exists only in politically organized society, nor only on the societal level. On the contrary, every functioning group or subgroup of a society may possess its own legal institution, which permits the group to function by compelling its members to conform to common norms of behaviour. A society is not usually composed of an undifferentiated group of actors. It is a patterned combination of subgroups with different memberships, functions, and degrees of inclusiveness. The very existence of any one of the subgroups is dependent upon the enforcement of its own legal norms. The existence of a legal institution is of vital necessity to any functioning subgroup because offenses within such a group cannot go unpunished, and because disputes cannot be allowed to continue indefinitely lest they destroy the group.

\section{DEVELOPMENT OF THE INSTITUTION OF LAW}

Having identified and described the rudimentary norms and actions which exist in all legal institutions, the next problem in describing law in universal terms is indicating how these rudimentary norms and actions develop so as to constitute the wide variety of legal institutions which exist or have existed. The solution to this problem lies in understanding the processes of institutional differentiation and specialization. The rudimentary norms and actions are the elements of the simplest legal institutions, as well as the most complex legal institutions, in the sense that they may exist in a wide variety of more or less differentiated and specialized forms.

In describing the development of the institution of law in the following pages, I will focus on the logical progression of increasing differentiation in normative law and legal action. This discussion of differentiation in the legal institution should not be commenced without identifying three ideas which are not implied by what will be said below. First, there is no implication that there is any necessity for increasing differentiation. In other words, increasing differentiation is not inevitable. Second, there is no implication that, once it has begun, differentiation will continue. Differentiation is not irreversible. Finally, there is no implication that there are stages of differentiation. Differentiation is not sequential.

In the simplest legal institutions, the rudimentary legal norms are undifferentiated. The norms of how the members of the group should act and the collective understanding of how these norms should be implemented are both embodied in similar precedents. These precedents are recollections of concrete situations in which certain actions were reacted to in certain ways. These precedents are norms in the sense that they are regarded as being applicable to all future cases involving similar actions.

Gradually, the norms of how the members of the group should act may separate from the norms of how the institutional structure should implement the norms of behavior. Substantive law becomes differentiated from institutional law. Certain precedents are remembered because they embody the proper actions in certain situations, while other precedents are remembered because they embody the proper procedure for the institutional apparatus.

Substantive law may further differentiate into private and public law. Private, substantive legal norms are best conceptualized in terms of rights and their reciprocal duties or obligations, and the parties to which they are attached. Some private legal norms confer upon certain actors the power to create a legal relationship consisting of rights and duties which are enforceable by legal coercion, while other norms prescribe the respective legal rights and duties of each party in the relationship. For example, in our legal system some legal norms confer the power to contract upon those who have reached the age of majority, and who are of a sound mind. Other legal norms prescribe that one who has performed a duty under a contract has a right to be paid a compensation for his performance, and that one who has received a benefit under a contract has a duty to pay for that benefit. The importance of conceptualizing private legal norms in terms of rights and duties is that all legal relations are between actors and not things. There can be no rights against things, but only rights against persons in respect to things. For example, legal norms concerning ownership of property do not prescribe rights of the owner against the property, but rather rights of the owner against 
all others in respect to the property. Private, substantive legal norms are regarded as protecting individuals or groups from injury by other individuals or groups.

Public, substantive legal norms are prescriptions of actions from which to refrain. In other words, public legal norms forbid certain actions. The prescribed, forbidden actions are regarded as harmful to the group as a whole, and thus public legal norms are regarded as protecting the group as a whole from injury. In one sense, all legal norms are concerned with resolving conflicts between actors. From this point of view, public legal norms are concerned with resolving conflicts between an individual (the violator) and the society as a collection of others.

The two fundamental types of institutional law, elaboration and enforcement norms, may also separate from each other. Those who are allocated the authority of elaborating the law may become different from those who are allocated the authority of enforcing the law. Accordingly, the norms governing those who are to elaborate the law will be different from the norms governing those who are to enforce the law.

Elaboration norms may further differentiate into at least three types of specialized elaboration norms: 1 ) norms of change or creation; 2) norms of interpretation; and 3) norms of form. Norms of change are collective understandings that new legal norms should be introduced and old ones repealed by deliberate enactment. It is collectively understood that a norm can only be endowed with, or deprived of, legal status by direct human action. Accordingly, prescriptions of change identify which individuals or groups should change the legal norms and what acts are required in doing so.

Legal norms of interpretation are collective understandings about who should determine the extent of the normative law (including the institutional law itself), the internal consistency of the normative law, and the precise meaning of particular legal norms; and how they should go about doing so.

Legal norms of form, the third type of specialized elaboration norms, are prescriptions about how legal norms (institutional as well as substantive) should be represented. They are prescriptions about whether legal norms should be represented in explicit abstract rules or in concrete precedents. Legal norms in the form of abstract rules generally do not exist outside Western civilization. There are many tribal societies, including those of the North American Indians, in which legal abstract rules simply do not exist; the members of these societies are reported to have no conception of legal norms in the form of explicit abstract rules. Even within the Western world, legal abstract rules are conceptualized differently in different legal systems. In most continental European legal systems, legal abstract rules are collectively understood as being the primary form of law. Consequently, it is agreed that they should be applied to cases involving actions which do not objectively match the prescribed actions of the abstract rules. On the other hand, in the North American and British legal systems, legal abstract rules are collectively understood as being only the secondary form of law (legal precedents or decisions being the primary form). Consequently, it is agreed that they should only be applied to cases involving actions which objectively match the prescribed actions of the abstract rules.

Like elaboration norms, enforcement norms may further differentiate into at least two types of specialized enforcement norms: 1) norms of adjudication; and 2) norms of reaction.

Legal norms of adjudication are collective understandings about who should make authoritative determinations about whether, on a certain occasion, particular concrete actions were contrary to the legal norms, and how this determination should be made. Adjudicative norms may further differentiate into at least three more specialized norms: detection, initiation, and forensic. Norms of detection prescribe who should discover concrete actions which might. be contrary to the normative law, and how they should go about doing so. Norms of initiation prescribe who should bring the case before the individual or group making the authoritative determination, which cases should be considered by the "court," which "court" should consider which cases if there are several "courts," and finally how the proper case should be brought before the proper "court." Forensic norms prescribe who should make the authoritative determination, what sequence of actions should be involved, what evidence can be considered, how 
the evidence can be gathered, what subset of substantive law is applicable, and what standards should be used for determining if the action in question violated the normative law. In some legal systems these three types of adjudicative norms are relatively simple, while in other legal systems they are relatively complex.

Legal norms of reaction, the second type of specialized enforcement norms, are collective understandings concerning: who should react to actions which have been determined to be contrary to the normative law; what reactions should be used and to what extent should they be limited; toward whom should the reactions be directed-the actual perpretrator, the group to which he belongs, or both; and what purpose or purposes should be accomplished by the reactions-protection of the group, reparation, revenge, expiation, deterrence, reformation, or reintegration.

The diagram on the following page summarizes the possible differentiations and specializations which may occur in the normative law.

Turning now to legal action, in the simplest legal institutions, the rudimentary legal acts are undifferentiated. The acts which elaborate the norms are not clearly separate from the acts which enforce the norms. When the institutional apparatus reacts to certain actions in certain circumstances, it is at the same time identifying particular norms.

Gradually, the elaborating acts may become separate from the enforcing acts. One individual or group may create, interpret, display, or state the normative law, while another individual or group may detect, adjudicate, and react to violations of the normative law. Even where they are carried out by the same actors, elaborating and enforcing acts may be differentiated if they are carried out at different times or places.

Once they are separated from enforcing acts, elaborating acts may further differentiate into more specialized sets of acts. There are at least two sets of more specialized elaborating acts: 1) acts exclusively changing normative law; and 2) acts exclusively interpreting normative law.

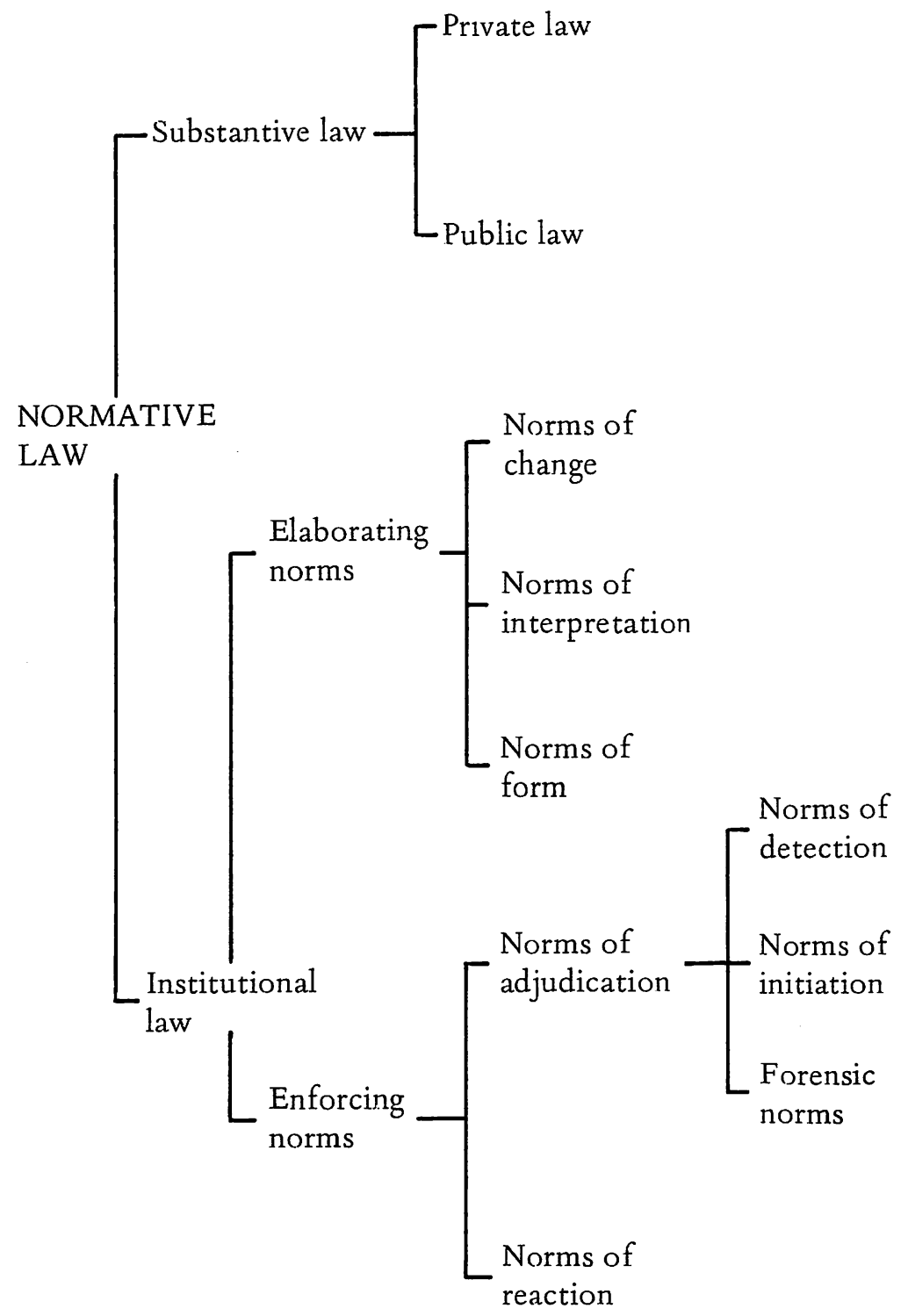


Acts changing normative law necessarily occur more or less frequently because norms can only become a part of, or be removed from, normative law by deliberate human action. A norm does not cease to be a part of normative law merely because the members of the group regard it is no longer important or worth maintaining. Acts changing normative law may involve interaction among all or part of those who are concerned, or they may involve imposition by a dominating individual or group.

Acts interpreting normative law may serve at least two functions. First, they may be directed toward the normative law itself, and thus function to develop, elaborate, and maintain the internal consistency of the normative law. Second, they may be directed toward those who are subject to the normative law, and thus function to advise or counsel those who are expected to follow the normative law. These acts of advising are not exclusive to Western societies for they exist in such societies as Cambodia, Indonesia, and Syria.

Like elaborating acts, enforcing acts may also differentiate further into more specialized sets of acts. There are at least two sets of more specialized enforcing acts: 1) acts exclusively adjudicating normative law; and 2) acts exclusively reacting to violations of the normative law.

Acts adjudicating normative law are those acts which are involved in the process of making authoritative determinations about whether, on given occasions, particular concrete actions were contrary to the normative law. Adjudicative acts may further differentiate into even more specialized acts: detection, initiation, and forensic. Acts of detection involve discovering or publicly complaining about concrete actions which might be contrary to the normative law. Such acts may be performed either by those directly involved or affected by the action in question, or by an independent actor or group of actors who act on behalf of the group as as whole. Acts of initiation involve deciding which actions or cases are to be considered by the "court," disengaging the appropriate cases from their nonlegal settings, and engaging them into the processes of the appropriate "court."

Forensic acts involve actually deciding whether the particular concrete actions in question were contrary to the normative law.
Such acts include listening to the claims of both sides to the dispute; selecting the evidence, legal norms, and standards which are appropriate; and weighing all the relevant facts. Forensic acts are influenced not only by normative law, but also by morality, custom, and social status of the actors involved, and subjective factors such as "fairness" and "justice."

Forensic acts are performed by one or more actors who constitute a "court." The essential characteristic of a court is authority. Any legal decision has to be accepted by the parties to a dispute or forced on them if they protest or resist. Obviously, not all members of a group can hand down such a decision. It requires an individual who has sufficient power at his disposal to enforce the decision, either by persuasion or by psychological or physical compulsion. In all groups there exist certain outstanding, important actors who regularly assume leadership and solve intra-group disputes. These actors initiate action in the group, resolve its problems, and occupy positions of greater or lesser importance. A "court," then, is one or more actors whose advice and decisions are usually followed by the rest of the members of the group.

Forensic acts may serve two functions. First, they may be limited only to the particular case in question, and therefore only serve to decide that a particular concrete action is contrary to, or in accordance with, the normative law. Second, in addition to deciding the particular case in question, a legal decision may be intended to be applied to all similar or "identical" cases in the future. Such a decision serves to establish a new norm which becomes a part of normative law.

Acts reacting to violations of the normative law, the second type of institutional legal acts, may take a variety of forms. One type of reaction is privileged force. Privileged force consists of positive acts for inflicting some painful experience-physical, psychological, or social. The force involved in these acts is privileged or legitimated because there is a low probability of retaliation by actors other than the actor or actors at whom the force is directed. Even if the actor who acts contrary to legal norms uses force to resist coercion, the coercion is privileged as long as other parties do not retaliate. Thus, coercion is not 
privileged when the perpetrator can rely on other actors using force to rally to his cause.

A second type of specialized reaction is psychological sanction. Psychological sanctions include such acts as ridicule, ostracism, avoidance, excommunication, and denial of favors which would have been granted had not the law been violated. A third type of reaction involves appeals to fear or interest. A fourth type of reaction is reparation or indemnification which involves the payment of something of value by one party to another party. A fifth type of reaction consists of acts designed to reform the offender or to reintegrate him back into the life of the group.

Reactions to violations of the normative law are carried out by a staff of one or more actors who hold themselves specially ready for that purpose. This staff holds itself specially ready to react, on its own initiative or at the request of others, to illegal action with coercive as well as noncoercive actions. This special staff is limited in number for it usually does not include all the members of the group in which it exists. Furthermore, the relationship between the special staff and the perpetrators of illegal action is universalistic, rather than particularistic. The special staff is reacting to the perpetrators as an arm of the group, rather than as a collection of interested individuals.

The special reaction staff carries out the reactions according to some traditional and recognized procedure. Reactions to violations of the normative law may also be carried out by members of the group acting as individuals. Expressions of resentment, disapproval, and indignation of illegal action are examples of such reactions (Timascheff, 1939). Yet, although these diffuse reactions are often more effective in enforcing the normative law than the organized reactions, they always remain supplemental to the organized reactions. The diffuse reactions are never regarded as sufficient in themselves to properly react to violations of the normative law. (Radcliffe-Brown, 1952).

Reactions to violations of the normative law may serve a variety of intended purposes. For instance, reactions may function as social defenses by which harm to the group as a whole is avoided; they may function to restore the social equilibrium which has been disrupted by the illegal action; they may function to deter future illegal action; or, they may function to compensate those injured by the illegal action. Alternatively, reactions may function to rehabilitate the offender, to rebuild solid ties between the offender and group life, or to maintain or reaffirm the normative law.

The following diagram summarizes the possible differentiations and specializations which may occur in legal action.

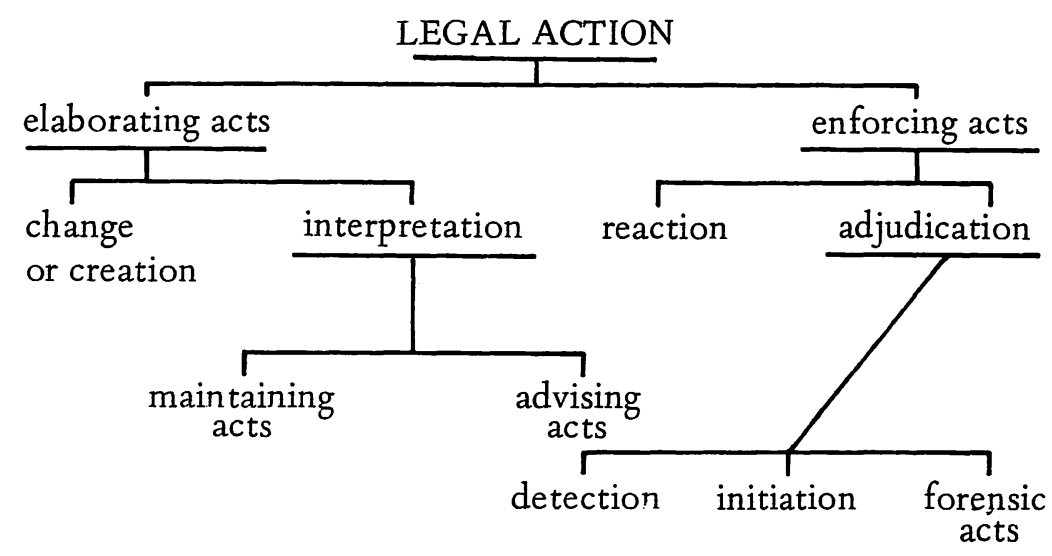

The central assertion in this discussion of the development of legal action is simply that differentiation occurs in legal action in the sense that there is an increasing division of labor with respect to legal action. The various types of legal action increasingly separate from one another in that each is assigned to special actors who exclusively perform one type of legal action. Elaborating acts are assigned to one special legal apparatus, while enforcing acts are assigned to another apparatus. Acts of change or creation are then assigned to an even more specialized apparatus, while acts of interpretation are assigned to another more specialized apparatus. Similarly, acts of reaction are assigned to a more specialized legal apparatus, while acts of adjudication are assigned to another more specialized apparatus. The process of differentiation thus occurs in legal action as legal acts become more specific, and are assigned to more specialized legal apparatuses. 


\section{CONCLUSION}

In analyzing a legal institution, it is very important to determine the level of differentiation of the institution as a whole because an important consequence of the increasing differentiation in legal action and in normative law is a greater and greater separation of the legal institution from the society as a whole. This separation may proceed to the point where the substance of what specialized legal actors do is quite different from what a common consensus prescribes as appropriate for them to do. Such a separation may exist even where the substance of what specialized legal actors do is entirely in conformity with institutional norms. Such a separation is possible because the institutional norms are themselves created by specialized legal actors, rather than by a common consensus of the society. Examples of this separation of the legal institution from the society as a whole are legal norms and actions which are unpopular in terms of the members of society, but which are perfectly legitimate in terms of the institutional norms.

All of this involves a strain between the legal institution on the one hand, and the larger society and its social organization on the other hand. This strain may be especially acute when the legal institution comes to serve one segment of a pluralistic society and not the other segments. This strain may lead to: 1) questions of the legitimacy of the existing legal institution; 2) attempts to change the existing institutional norms; or 3) attempts to set up a competing legal institution, or to disrupt the functioning of the established legal institution.

\section{REFERENCES}

Bohannon, Paul

1967 "The Differing Realms of the Law," in Paul Bohannon, ed. Law and Warfare (Garden City, New York: the Natural History Press).
Feeley, Malcolm

1976 "The Concept of Laws in Social Science: A Critique and Notes on an Expanded View," in Law and Review (Vol. 10).

Freund, Julian

1968 The Sociology of Max Weber, Mary Ilford, transl. (New York: Pantheon Books).

Fuller, Lon

1969 The Morality of Law, Revised ed., (New Haven: Yale University Press).

Gibbs, Jack P.

1973 "Definitions of Law and Empirical Questions," in Michael Barkun, ed., Law and the Social System (New York: Lieber-Atherton).

Gluckman, Max

1965 Politics, Law and Ritual in Tribal Society (Chicago: Aldine Publishing Company).

Hart, H.L.A.

1961 The Concept of Law (London: Oxford University Press).

Hoebel, E. Adamson

1973 The Law of Primitive Man (New York, Atheneum) First published 1954.

Hohfeld, W.N.

1923 Fundamental Legal Conceptions as Applied in Judicial Reasoning and Other Essays, W.W. Cook, ed. (New Haven: Yale University Press).

Holmes, Oliver Wendall

1968 "The Path of Law," in Rita Simon, ed., The Sociology of Law (San Francisco: Chandler Publishing Company). 
Mid-American Review of Sociology

Pospisil, Leopold

1972 "The Ethnology of Law," in Addison-Wesley Modular Publications (Module 12).

Pound, Roscoe

1944 The Task of Law (Lancaster, Pennsylvania: Franklin and Marshall College).

1943 "What is Law," West Virginia Law Quarterly (Vol. 47). Radcliffe-Brown, A.R.

1952 Structure and Function in Primitive Society (New York: The Free Press).

Radin, Max

1938 "A Restatement of Hohfeld," Harvard Law Review, 51:1141-1164.

Redfield, Robert

1967 "Primitive Law," in Paul Bohannon, ed., Law and Warfare (Garden City, New York: Natural History Press).

Schwartz, Richard D. and Miller, James C.

1964 "Legal Evolution and Societal Complexity," American Journal of Sociology, 70:159-69.

Selznick, Philip

1961 "Sociology and Natural Law," Natural Law Forum, 6:84-108. Selznick, Philip

1968 "The Sociology of Law," in Rita James Simon, ed., The Sociology of Law (San Francisco: Chandler Publishing Company).

Schur, Edwin

1968 Law and Society: A Sociological View Point (New York: Random House).
A Definition of the Concept of Law

Sumner, William, Graham

1967 "The Mores and Institutions" in Ephram H. Mizurchi, ed. The Substance of Sociology (New York: Meredith Corporation).

Timascheff, Nicholas A.

1939 An Introduction to the Sociology of Law (Cambridge: Harvard University Press).

Warriner, Charles K.

1970 The Emergence of Society (Homewood, Illinois: The Dorsey Press).

Warriner, Charles K.

1976 "Society, Culture, and the Person: A Formulation of the Ontological Relations of Central Sociological Concepts," unpubl.

Weber, Max

1954 Law in Economy and Society, Max Rheinstein, transl. and ed. (Cambridge: Harvard University Press). 